\title{
Integration of health service with electronic nursery care process
}

\author{
Yeliz Doğan Merih a , and Kerime Derya Beydağ ${ }^{2}$ \\ ${ }^{1} \mathrm{PhD}$, Dr. Zeynep Kamil Women and Child Research and Training Hospital, Istanbul/ Turkey \\ ${ }^{2}$ Faculty of Health Science, Department of Nursing, Okan University, Turkey
}

\begin{abstract}
You This study aims to provide to integrate the health service with electronic nursery care process and so do create lingua franca. This research has been done between April 2010 and January 2012 in a teaching and research hospital where is specialized on obstetrician and gynecology. 280 nurse are the sample of the study. The datas are collected by using a survey with 22 questions. After the observations and evaluations, in case of standards 40 nursery care process about most experienced problems in gynecology, obstetrician and pediatry clinics is formed and its infrastructure for integrating these flow diagrams to the data processing system is prepared. For working the new system, instructive sessions is done. After the applications, the using of process approach in nursery care service and the pleasure of the nurses are analysed. The datas are analysed by using percentage calculation, t-test and variant analysis test in case of SPSS programme. In this study, 3 different application for the usage of process approach is used. These applications are done in different 15 bedded clinics and in differrent times. In the first application, empty forms which have standard format, are given to the nurses to complete.In the second application, the forms which special nursery activity has been wrritten on, are given to the nurses to sign their own activity and in the third application, the standard process approach which has been integrated to electronic system and which is special to patient, is requested to use. After all aplications, according to analysation of the results, the usage of the process' method rates are; $10 \%$ is for first method, $40 \%$ is for second method and $90 \%$ is for third method. Especially, the nursery process approach which has been integrated to electronic system is used more desirous. According to the nurses' opinion, this system increases the creation of lingua franca, data security and effective time management. It is determined that their pleasure is much more than the other methods and their belief to this system increases $(\mathrm{p}<0.01)$
\end{abstract}

Keywords: Electronic Process, nursery, service

${ }^{\text {a }}$ Corresponding author: derya.beydag@okan.edu.tr 


\section{Introduction}

The provision of health care has changed dramatically in recent years. Changing and evolving health care system affects the basic health needs of people and so the health care approach. All health professionals who are involved and take charge in this care approach must move with the changes and be open for improvement. 1

The birth of nursing that is one of the oldest health professions goes back ancient times. The nursing history has started with the therapeutic (healing) role of women. Today, the goal of health care is to provide quality care. The nurses must give effective care to their patients with constantly updated information. In general, the purpose of nursing is to support, maintain the health of person or improve the level of health [1-4].

Today, the nursing profession has become a medical discipline that its theories and practices are based on the scientific basis by showing great improvements. The modern nursing adopts a systematic approach to organize and provide nursing care in all care environments of person with undertaken contemporary roles, by providing the best nursing care. This approach is the nursing process [3-4].

The nursing process that provides a professional identity to nursing profession is a systematic, scientific problem solving method that is used in determining the health care requirements of healthy / sick person and in individualized care [5]. The World Health Organization (WHO) defines the nursing process as a systematic approach of scientific problem solving method in nursing care [6].Various classification systems are using for nursing process that forms the basis of the scientific process. Some of those are North American Nursing Diagnosis Association (NANDA), Nursing Interventions Classification (NIC) and Nursing Results Classification (NOC) [7]. Nursing process includes these five stages; data collection, nursing diagnosing, determining the outcome criteria, planning / implementation and evaluation [8].

Nursing process is a systematic method that is used in determining care needs of sick or healthy person and in individualized care and it depends on interpersonal interaction. Because, this process is required to one-to-one, direct and constant interaction and communication with patient to meet the patient's needs. Nursing process is planned and goal-oriented. Between nurses and patients, in a planful manner, it is a creative tool to solve the patient's identified health problems. Nursing process focuses on feedback that provides to reveal the problem again and to revise the care plan again [9-11].

The duties and responsibilities of nurses are given relying on the nursing process in Article 4 of the Law No. 5634 which is related to making amendments on Nursing Act (No. 6283). According to Law No. 5634, nurses must ground their applications to nursing process. However, in the studies conducted on both nurses and students, it was determined that nurses did not use the nursing process at desired level [12].

Nursing diagnosis determined by the students on neurological patients, it was determined that students were insufficient in the selection of initiatives towards determined nursing diagnosis [13].

Literature and conducted studies indicate that the nursing process is not used enough in application. It was observed that the nursing process is used in some health facilities, but some difficulties were experienced when applying. To use the nursing process effectively in the service area; to properly teach the nursing process to students during basic nursing education, to provide training for using the process in service training for use nurse in the field, to activate application facilitating systems in order that nurses who work in institutions use the process approach in their service are important [4].

To organize the standards for nursing practices and becoming effective of process approaches provide the service to acquire a meeting the requirements, effective, suitable for time management, observing patient-employee satisfaction, has certain limits, provide 
access to objective and measurable property. In our study it is aimed to active use of processes and create a common language in service delivery by ensuring the integration of electronic nursing process approach to services.

\section{Method}

This descriptive study was conducted as a quasi-experimental study between 25 April 2010- January 2012, in a maternity and children's hospital on the Anatolian Side of Istanbul.

\subsection{Participants}

The research sample: The research sample has created by 280 nurses who actively work in working time in maternity and child clinics of the related hospital and agreed to participate in the study.

\subsection{Procedure}

The data were collected by 22 question survey that was formed by researchers to measure socio-demographic, occupational characteristics, views towards using of the nursing process (the first 10 questions) and the satisfaction about used maintenance process methods before and after application (12 question, 4 likert) of participants by researchers. The data of research were obtained by filling the surveys by talking face to face with nurses. Nurses had totally 20 minutes to fill the survey.

In research process in order to activate the process approach in the hospital nursing service before all nurses provided training for nursing process, scope, implementation steps, benefits and successful examples. After awareness training nurses were provided to use three methods at different times in process applications. The consulting and control approaches were activated by about subject experienced researchers on work in all applied processes.

Three different process application methods were applied at different times in our hospital's 15 inmate service.

- In the first method; the patient-based, manually using of forms was requested by giving in a standard format empty process forms to nurses. The first method has been provided to be used in all clinics of the hospital, evaluation surveys were applied to nurses before and after the usage to make them evaluate the application.

- In the second method; standard full forms in which diagnoses-specific nursery activities are written were provided to participants, and nurses were asked to mark the activities they did on patient basis. After the first method was ended, the second method was provided to be utilized in all clinics of the hospital for 3 months, evaluation surveys were applied to participating nurses before and after the usage to make them evaluate the application.

- In the third application; the third application process was activated after the first two application has ended.

The steps of third application are as follows.

- Following the evaluations, 40 nursery care process (data collection, diagnose, planning, application, evaluation) in total were created at first within the scope of standards for most common problems of nurses they encounter in gynecology and pediatric clinics. 
- Researchers and IT employees started a joint working programme, together they creted the software steps of electronic nursery process.

- The created 40 nursery process were integrated into the configured electronic software process on step basis.

- Information meetings were held for the created system and operatability was provided.

- The integrated electronic care process was applied as pilot in a gynecology and pediatric service, healing processes were initiated after the application.

- The finalized electronic nursery process was integrated into service and started to be applied in all clinics for a period of 3 months.

- After the application, the usage of process approach in nursery services and satisfaction of the nurses were evaluated.

For the research, the required permissions were granted from the hospital's ethics committee and hospital administration. The participants were informed in writing that their identities would be kept hidden and the information would be used only for this research, consent was taken. In evaluation of the research; percentage calculation, $t$ test and variance analysis tests were used within SPSS programme.

\section{Findings}

It was identified that $43.2 \%$ of the participants were in $20-25$ age group, $81.8 \%$ of them had bachelor and master's degree and $36 \%$ of them had 2-5 years of professional experience (Table 1).

Table 1. Distribution of Participants According to Their Demographic and Professional Characteristics $(n=280)$

\begin{tabular}{|c|c|c|c|}
\hline \multicolumn{2}{|l|}{ Characteristics } & Number & $\%$ \\
\hline \multirow{5}{*}{ Age groups } & $20-25$ & 121 & 43.2 \\
\hline & $26-31$ & 81 & 29.0 \\
\hline & $32-37$ & 45 & 16.0 \\
\hline & $38-43$ & 19 & 7.0 \\
\hline & +44 & 14 & 5.0 \\
\hline \multirow{4}{*}{ Educational Status } & High School & 6 & 2.1 \\
\hline & Associate Degree & 45 & 16.1 \\
\hline & Bachelor's Degree & 192 & 68,6 \\
\hline & Master's Degree and Above & 37 & 13.2 \\
\hline \multirow{4}{*}{ Professional Experience } & $0-1$ year & 39 & 14.0 \\
\hline & $2-5$ years & 101 & 36.0 \\
\hline & $6-10$ years & 59 & 21.0 \\
\hline & +10 years & 81 & 29.0 \\
\hline \multicolumn{2}{|l|}{ Total } & 280 & $\mathbf{1 0 0 . 0}$ \\
\hline
\end{tabular}

In order to determine the opinions of participants on the process issue before the application, it was identified that $68 \%$ of them had education on nursery process before, that $64 \%$ of them did not find themselves sufficient, and that $79 \%$ of the participants stated the electronic process approach in the first place in reply to question of which method they would prefer to apply the nursery process if they were to apply the process (Figure 1). 


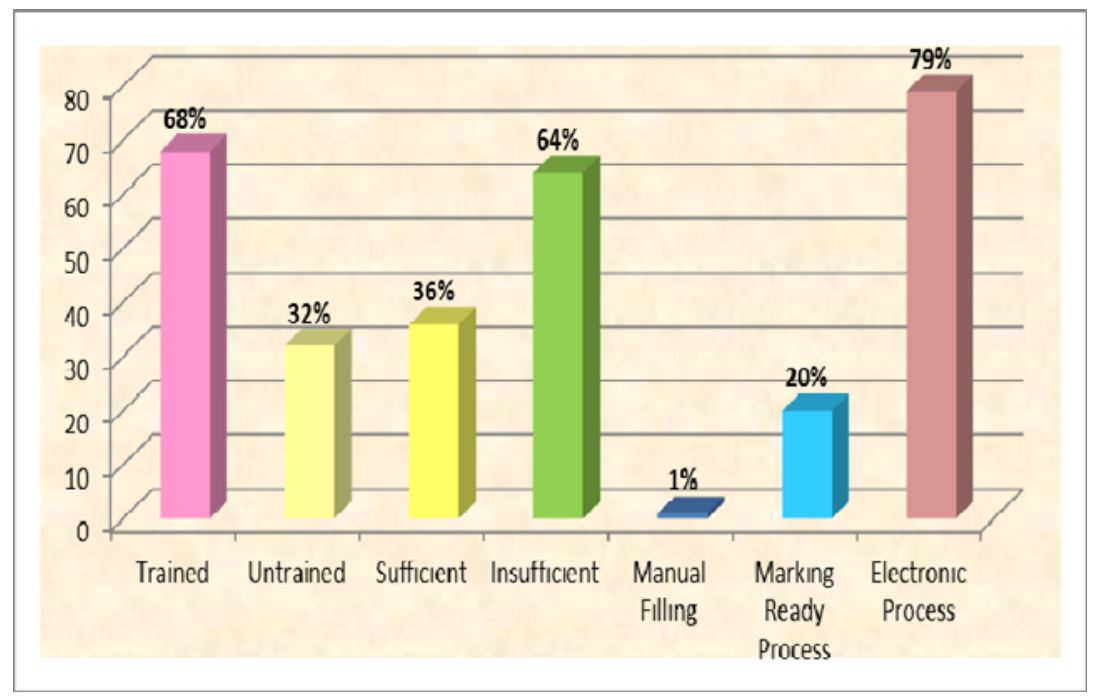

Figure 1: Opinions of Participants for Nursery Processes $(n=280)$

In result of the evaluation made after all the applications, it was determined that the using rates of process methods for participants were $10 \%$ in the first application whereas $40 \%$ in the second application and $90 \%$ in the third one. When test results before and after the application for the three methods were compared, it was determined that there was a significant increase only in electronic nursery application $(\mathrm{p}<0.01)$, and that satisfaction for nursery process application was at high level (Table 2).

Table 2. Evaluations of Participants for Process Applications Before and After The Application $(\mathrm{n}=280)$

\begin{tabular}{|l|l|l|l|l|l|l|}
\hline $\begin{array}{l}\text { Form For Evaluating The } \\
\text { Effectiveness of Process } \\
\text { Applications }\end{array}$ & Average & $\mathbf{n}$ & $\begin{array}{l}\text { Std } \\
\text { deviation }\end{array}$ & Std Error & $\begin{array}{l}\text { Statistical } \\
\text { Test (p)* }\end{array}$ \\
\hline $\begin{array}{l}\text { Manual } \\
\text { Application }\end{array}$ & Pre-test & 3,4899 & 280 & 0,46916 & 0,03979 & t: 1,465 \\
\cline { 2 - 7 } & Post-test & 3,5065 & 280 & 0,19568 & 0,01660 & p: 0,243 \\
\hline $\begin{array}{l}\text { Ready Process } \\
\text { Forms }\end{array}$ & Pre-test & 3,5125 & 280 & 0,54149 & 0,04593 & t: 1,194 \\
\cline { 2 - 6 } & Post-test & 3,7094 & 280 & 0,24538 & 0,02081 & P: 0,161 \\
\hline $\begin{array}{l}\text { Electronic } \\
\text { Nursery Process }\end{array}$ & Pre-test & 3,5387 & 280 & 0,55397 & 0,04699 & t: 9,211 \\
\cline { 2 - 6 } & Post-test $: 0,000$ \\
\hline
\end{tabular}

*(Paired Samples t-test $=0.000 p<0.01)$

\section{Discussion}

In hospitals, which serve on a very critical and an important topic as human health, our entire information should be accurate and the process in our health related procedures should run accurately. Within this process, integration of service records of health team members into hospital information management system (HIMS) is quite important. Today, using of IT in service processes of nurses are not at desired level. 
In order to exist in the changing and developing world order, nursery should keep all its channels open, get stronger by ongoing professional trainings, adapt the change by integrating its knowledge into HIMS. Here in this process, informatics and the records providing the professional visibility have great importance $[4,14,15]$. In our study, based upon the importance and necessity of process systems, it was aimed to provide the integration of electronic nursery care process approach into the service and use the processes actively and create common language in service presentation.

It was determined that $43.2 \%$ of participants were in $20-25$ age group, $81.8 \%$ of them had undergraduate and higher education and $36 \%$ of them had 2-5 years of professional experience. It was determined that the majority of nurses participated in our study consisted of young group of nurses who had undergraduate study. When characteristics of participants were considered, it was set forth that it was a group having effective knowledge in nursery process topic. However, it was identified that the participants did not have awareness on nursery process topic as much as they were expected to. This circumstance brought us to the finding that the education of nurses on nursery process topic might be insufficient.

As the nursery students graduate by experiencing problems related to nursery process, their use of nursery process when they become nurses are also negatively affected. In a study conducted by Lea et al, it was identified that the information of students on nursery process was not at the level desired by the school [16]. Although students state that they find nursery process useful and apply it, this result shows that students have deficiencies and these have to be completed.

In the survey carried out in our study with intent to determine the opinions of participants on the process before application, it was identified that $68 \%$ of them had previous education on nursery process, that $64 \%$ did not find themselves adequate and that they stated electronic process approach in the first place with a rate of $79 \%$ in reply to question with which method they would apply the nursery process if they were to apply it (Figure 1).

The nursery process, which brings a scientific identity to nursery applications, has a lot of benefits for nurses and student nurses. One of such benefits is providing individual centered nursery care [17]. The other one provides that the nurse gives care in line with a plan and thus uses her time more effectively. Furthermore, it develops the communication between team members, creates written sources and proofs for nursery education and researches and thus makes nursery services visible [18-19].

The nursery process, which is a model that brings solution to nursery problems, is taught as an important element of nursery education. However, although the nursery process - the application of scientific method to nursery care - is taught to students in scope of nursery education, students still have difficulties in preparing care plan. Furthermore, he states in a more challenging aspect that it is remarkable as the students can not bring care plan even to application stage [20]. And this reveals that the education in such schools fail to accomplish this purpose. The students, who are graduated without learning to work with nursery process and understanding the importance of working with the process, do not use nursery process also when they are graduated or resist to use it [21-22]. In our study, the statements of nurses that they did not have sufficient education on process topic and find themselves inadequate about the process supports the study results.

As the result of evaluation made after all the applications in our research, the rates for participants' process method use was determined as $10 \%$ in manual process application whereas $40 \%$ in application of standard forms and $90 \%$ in electronic process application. When test results before and after the application for the three method are compared, it was determined that there was significant difference only in electronic nursery process 
application $(\mathrm{p}<0.01)$, and that there were much satisfaction from electronic nursery process application.

With the writing of nursery process, care plan is created. While writing the care plan, an applicable one should be prepared and this care plan should be up-to-date, effectual, right and compliant to environment. An ideal registration plan should have the features such as easy readability, easy to be filed, fast registration, applicability to computer, being in accordance with the institution's standards, easy to access information, allow to register the patient's needs from physical, psychological and sociocultural aspects, fit the purpose of health professional. The advantage of using standard care plans is that no new care plan is created for each patient and thus it saves time [23, 24].

In the study conducted by Yildırım, it was revealed that the nurses had no sufficient information regarding nursery process, that nursery process was not handled as a whole but as individual function parts and not reflected to the application [25]. However, due to a large variety of reasons, nurses do not use nursery process in clinics. According to Yilmaz, the reasons why nurses do not use the process can be listed as follows; they do not want to use the nursery process, there are a great number of patients in the service that the nurses are responsible to care for, increase in workload; active clinics do not lean towards nursery process applications, think that it does not contribute to patient care, do not know how to apply it [26].

In our study, it was determined that electronically integrated nursery process approach was used more willingly by nurses among the process methods due to being standard and providing ease of use. It was determined that nurses stated as electronic process increased creating common language, registration security and effective time management, that their satisfaction from the system was more than the other methods and their commitment to the system increased, and that our findings were consonant with literature information and study results.

\section{Conclusion and Suggestions}

Using of care processes in nursery is important in terms of making effective decision, presenting integrated approach, providing effective team work, preventing medical faults and providing effective time management.

-In our study, it was determined that the participants had medium knowledge level regarding process approach, that they felt themselves insufficient regarding the application of nursery process and leant more towards electronic nursery process if they had to apply it.

-It was determined that the extensive nursery process training, which was provided for nurses before the three different processes in our hospital, was important for increasing the awareness of nurses and that the nurses behaved more willingly in process applications after the training.

-As the result of evaluation made after all the applications in our research, the rates for participants' process method use were determined as $10 \%$ in manual process application whereas $40 \%$ in application of standard forms and $90 \%$ in electronic process application.

-As the test results before and after the application for the three methods are compared, it is determined that there is significant increase only in nursery process application $(\mathrm{p}<0.01)$ and satisfaction from electronic nursery process is at high level.

In parallel to study results, the following suggestions are made: 
-To increase the time allocated for nursery process in nursery curriculum programmes and nursery in-service trainings in the field.

-To provide references (book, magazine) which the students and nurses might benefit regarding the process.

-By making cooperation between school and hospital, encouraging the students and nurses in the field for patient-oriented work.

-To develop practical registration systems in health institutions for the use of all nurses; which are standard, provides ease of use and includes all steps of the process.

-To create management supported electronic nursery registration systems in hospitals and provide continuous healing.

\section{Acknowledgment}

Regarding the research and/or authorship of this article, the authors didn't receive any financial

\section{References}

1. Esatoğlu AE, Ersoy K. Hasta Tatmininin Ölçülmesi. İçinde: Çoruh M, Editör. Sağlık Hizmetlerinde Toplam Kalite Yönetimi Ve Performans Ölçümü. Haberal Eğitim Vakfi; 61-71., (1997).

2. Kocaman G., Türkiye'de Hemşirelik Eğitim Sorunları. 12 Mayıs 2003 Dünya Hemşireler Günü. Özel Baskı: 71-91.,(2003).

3. 14. Sabuncu N., Editör. Hemşirelik Bakımında İlke Ve Uygulamalar. Ankara: Alter Yayıncılık Org. Tic. Ltd. Şti.; (2008).

4. Keski Ç., Karadağ A., Son Sınıf Hemşirelik Öğrencilerinin Hemşirelik Süreci Hakkında Bilgi Düzeylerinin İncelenmesi, Gazi Üniversitesi Sağlık Bilimleri Enstitüsü Hemşirelik Programı Yüksek Lisans Tezi, Ankara, (2009).

5. Birol L., Hemşirelikle İlgili Kuramlar, Hemşirelik Süreci (Editör: Leman Birol), Etki Matb. Yayıncılık Ltd. Şti, İzmir,51-102., (2005).

6. Velioğlu P., Hemşirelikte Kavram Ve Kuramlar, Alaş Ofset, İstanbul., (1999)

7. Carpenito L., Hemşirelik Tanıları El Kitabı (Çeviri: Firdevs Erdemir), Nobel Kitabevi, Ankara., (2004).

8. Corder J., Nursing Process As A Therapetic Frameworks. In: Delaune S C, Ladner P K (Eds) Fundamentals Of Nursing Standards \& Practice, Delmar Publishers, Albany, Newyork, 297-306., (1998).

9. Sabuncu N., Editör. Hemşirelik Bakımında İlke Ve Uygulamalar. Ankara: Alter Yayıncılık Org. Tic. Ltd. Şti. (2008).

10. Bayat M., Öğretim Süreci Ve Hemşirelik. Sağlık Bilimleri Dergisi. ( Ek Sayı: Hemşirelik Özel Sayısı)14: 66-72., (2005).

11. Sorrentino AS. Mosby's Textbook for Nursing Assistants. 6th Ed. Missouri: Mosby Company, (2004).

12. Sağlık Bakanlığı. Hemşirelik Kanununda Değişiklik Yapılmasına Dair Kanun. Kanun Numaras1: 5634. Kabul Tarihi: 25.4.2007. Yayımlandığı Resmi Gazete: Tarih: 2.5.2007 Say1: 26510.

13. Karadakovan A., Usta Yeşilbalkan Ö., Öğrencilerin Nörolojik Hastalarda Saptadıkları Nanda Hemşirelik Tanılarının İncelenmesi. Atatürk Üniversitesi Hemşirelik Yüksekokulu Dergisi, 7(3), 1-7., (2004).

14. Birol L. Hemşirelik Süreci. 8. Baskı. İzmir: Etki Matbaacılık; (2007). 
15. Bayat M. Öğretim Süreci Ve Hemşirelik. Sağlık Bilimleri Dergisi. ( Ek Sayı: Hemşirelik Özel Sayısı)14: 66-72., (2005).

16. Lea SF, Anema MG, Briscoe VJ, Allie H., The Nursing Process: What Do Students Know? The ABNF Journal, 12,1: 3-8., (2001).

17. Sorrentino As., Mosby's Textbook For Nursing Assistants, 6th Ed, Mosby Company, (2004).

18. Potter AP., The Nursing Process And Critical Thinking In Potter Ap, Perry Ag (Eds) Fundamentals Of Nursing Concepts, Process And Practice, 4th Ed, Mosby Company, St.Louis, (1997).

19. Boroski B., The Medical Surgical Nurse. In Burke Km, Lemone P, Mohn-Brown El (Eds), Medical- Surgical Nursing Care, Pearson Education Inc. (2003).

20. Uyer G., Türkiye'de Hemşirelik Yönetiminde Değişen Ve Gelişen Yaklaşımlar, III. Ulusal Hemşirelik Kongresi Kitabı, Esnaf Ofset Matbaacılık, Sivas, 133-136., (1992).

21. Güner P, Terakye G., Hemşirelik Yüksekokulları Son Sınıf Öğrencilerinin Hemşirelik Tanılarını Belirleyebilme Düzeyleri, Cumhuriyet Üniversitesi Hemşirelik Yüksekokulu Dergisi, 4(1), 9-15.,(2000).

22. Taşdemir, G., Kızılkaya, M. Sağlık Yüksekokulu Son Sınıf Öğrencilerin Ruh Sağlığı Ve Hastalıkları Hemşireliği Dersi Klinik Uygulamasında NANDA Hemşirelik Tanılarının İncelenmesi. International Journal of Human Sciences. (10)1, 246-257., (2013).

23. Lipe S., Beasley S. Critical Thinking İn Nursing A Cognitive Skills Workbook. Lippıncott Williams \& Wilkıns United States Of America, 87-120., (2004).

24. Yıldırım B. Hemşirelikte Eleştirel Düşünme Uygulamalı Yaklaşım. Ed: Süheyla Altuğ Özsoy, Tuna Matbaacılık, Aydın., (2010).

25. Yıldırım A. Yataklı Tedavi Kurumlarında Çalışan Hemşirelerin Hizmetlerinde Yer Alması Gereken Hemşirelik İşlevleri Hakkında Bilgi Düzeylerinin Araştırılması. Yüksek Lisans. İstanbul: İstanbul Üniversitesi; (1988).

26. Yılmaz N. Hemşirelerin Hemşirelik Sürecine İlişkin Bilgi Ve Görüşlerinin İncelenmesi. Yüksek Lisans. İstanbul: Ege Üniversitesi; (2000). 